Research Article

\title{
Alternative Cement-Treated Base Construction with Class A Aggregate Mixtures in Provincial Road Maintenance Periodic in West Java
}

\author{
Yudi Sekaryadi, Anastasia Caroline Sutandi \\ Departemen of Civil Engineering, Parahyangan Catholic University, Bandung, Indonesia \\ Email address: \\ yudisekaryadi65@gmail.com (Y. Sekaryadi), caroline@unpar.ac.id (A. C. Sutandi)
}

\section{To cite this article:}

Yudi Sekaryadi, Anastasia Caroline Sutandi. Alternative Cement-Treated Base Construction with Class A Aggregate Mixtures in Provincial Road Maintenance Periodic in West Java. American Journal of Construction and Building Materials. Vol. 3, No. 2, 2019 , pp. $35-42$. doi: 10.11648/j.ajcbm.20190302.13

Received: July 4, 2019; Accepted: September 27, 2019; Published: December 4, 2019

\begin{abstract}
To handle roads that have a subgrade with a CBR (California Bearing Ratio) of less than 2\% and a plasticity index of more than $20 \%$, one of them is by using CTB (Cement Treated Base) pavement on the foundation layer. CTB is a mixture of materials consisting of coarse aggregates, fine aggregates, cement, and water. Periodic maintenance of roads in the southern part of West Java Province uses a pavement structure that is, AC-WC as a surface layer, CTB as the upper foundation layer, class A aggregate, as the lower foundation layer. Based on the contract time calculation, there will be a delay in the execution of the work, because the quary material is only 1 location and there is a build-up of mixing and mixing of coarse and fine aggregates to meet the mixture of CTB and class A aggregates. A is only one aggregate fraction so that in the quarry material only one time is made and mixed. Research on the nature and characteristics of the aggregate obtained results, namely the volume volume of the CTB mixture using a class A aggregate mixture: portland cement (1\%), water (2.08\%), fine aggregate $(3.41 \%)$, and coarse aggregate $(4.74 \%)$. While the results of the concrete compressive strength test on the mixture of CTB with CTB aggregate obtained an average compressive strength value of $127.70 \mathrm{~kg} / \mathrm{cm}^{2}$ greater than the planned compressive strength of $125 \mathrm{~kg} / \mathrm{cm}^{2}$. For CTB mixture using CTB aggregate, it becomes: Portland cement (1\%), water (1.0\%), fine aggregate $(2.70 \%)$, and coarse aggregate $(3.20 \%)$. While the concrete compressive strength test results on the mixture of CTB with CTB aggregate obtained an average compressive strength value of $126.80 \mathrm{~kg} / \mathrm{cm}^{2}$ greater than the planned compressive strength of $125 \mathrm{~kg} / \mathrm{cm}^{2}$. After modification of the pavement type, the road pavement structure becomes a surface layer with $4 \mathrm{~cm}$ thick AC-WC, the upper foundation layer uses CTB with class A thick aggregate 20, the lower foundation layer with class A aggregate $20 \mathrm{~cm}$ thick, and the original soil as a subgrade layer.
\end{abstract}

Keywords: Road Periodic Maintenance, Cement Treated Base, Base Layer, Class A Aggregate

\section{Introduction}

West Java Province is one of the provinces in Indonesia, geographically located at position $104^{\circ} 48^{\prime \prime}-108^{\circ} 48^{\prime \prime}$ East Longitude and $5^{\circ} 50^{\prime \prime}-7^{\circ} 50^{\prime \prime}$ South Latitude. West Java Province has an area of $37,087.92 \mathrm{Km}^{2}$ with the authority to manage sea 0 - 12 miles and an area of $1,552,890.67 \mathrm{Ha}$. The southern part of West Java is bordered by the Indian Ocean and stretches along $410 \mathrm{~km}$, starting from Cisolok, Sukabumi district to the Kalipucang border, Camis Regency. Southern West Java has many natural resources and no less than 20 interesting tours. Along the southern part of West Java, there are also several centers of agricultural production, agribusiness, fisheries, livestock and plantations and have many renewable energy sources such as geothermal power plants, micro-hydro power plants [12].

The potential and natural resources in the southern part of West Java, have not been utilized optimally by the people of South West Java because they have not been explored properly, resulting in economic growth in South West Java increasingly lagging. The phenomenon of South West Java's economic quality, can be seen from the rate of economic 
growth (LPE) as one indicator, which illustrates the progress of the regional economy. The average LPE in the southern part of West Java before the global financial crisis only reached around $3.5 \%$ to $4.5 \%$ [14]. This growth rate is lower than the LPE achieved by West Java Province and nationally. Meanwhile, regional own-source revenue is also less encouraging, especially in supporting the financing of the regional development process. This situation resulted in most of the southern West Java region still dependent on the budget of the Central Government.

Based on these conditions, the southern part of West Java Region requires a more serious handling, the most basic problem is accessibility, namely the road network system and the carrying capacity of the land. The road network system in southern West Java, especially in the Cianjur Regency Area (as a research location) is supported by national roads that stretch horizontally along the south coast of West Java and are connected vertically by provincial roads. A map of the road network system in West Java is presented in Figure 1 [15]. Soil carrying capacity in southern West Java in general has a CBR below 2\% and a Plasticity Index above 20\% with subgrade conditions that have very high shrinkage (expansion)) [8]. These conditions make it difficult to plan the ideal pavement that will be used, as can be seen in the existing road section presented in Figure 2.

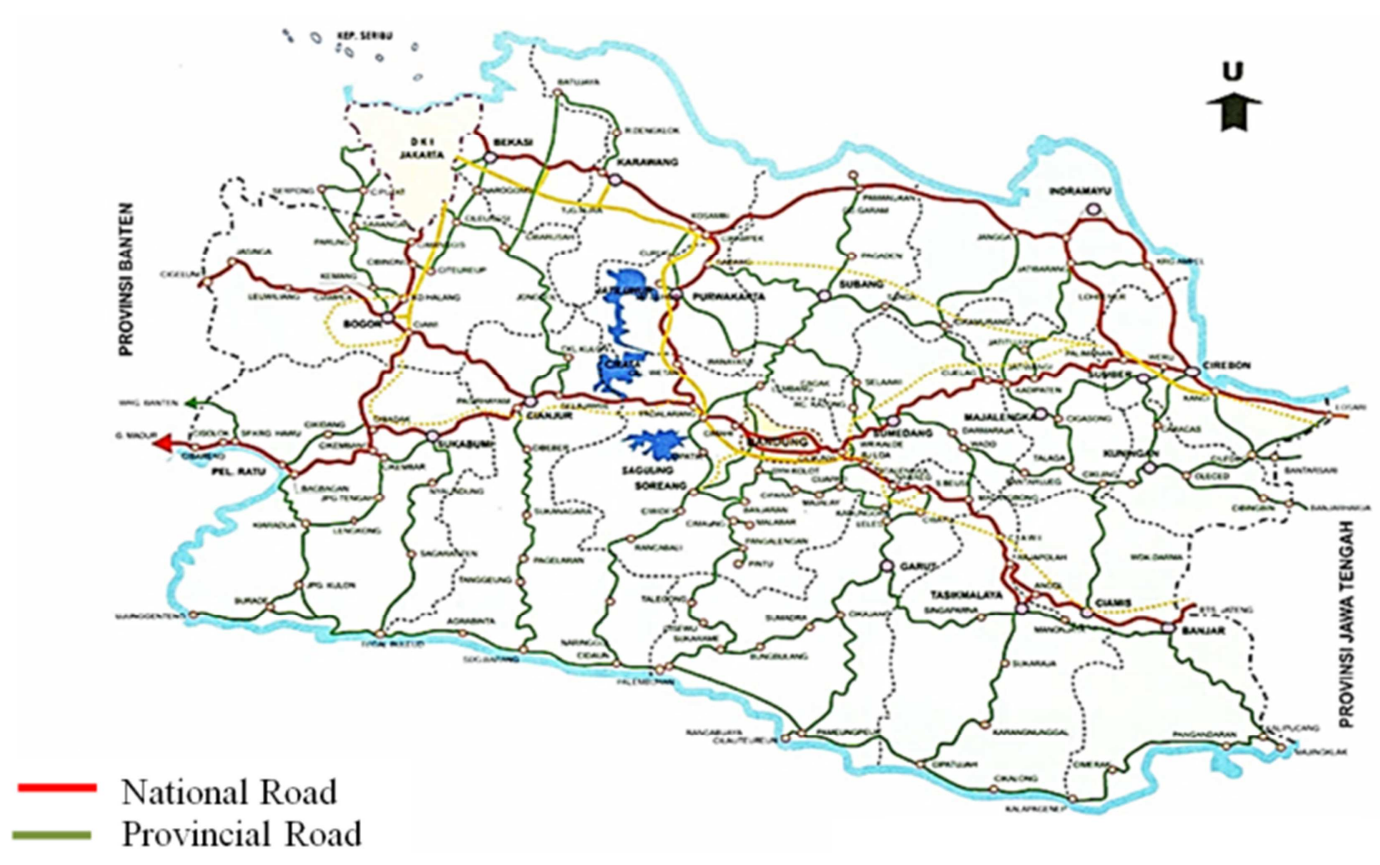

Figure 1. Road Network System in West Java.

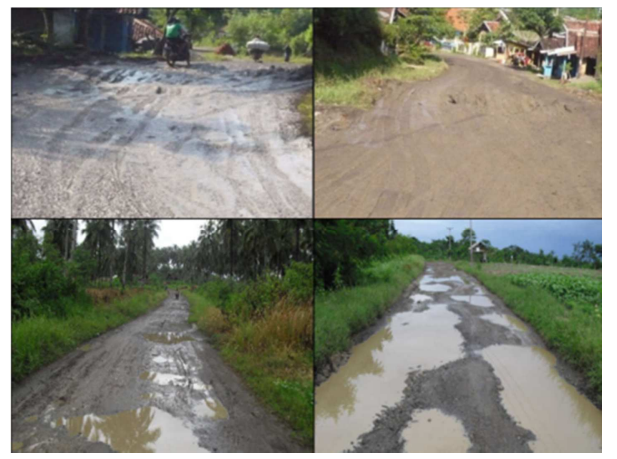

Figure 2. The condition of existing roads in the southern part of West Java before hardening with CTB.

In figure 2 it can be seen that the road conditions are unstable, in the rainy season the ground is watery and it is very difficult to dry because the plastic index is high. While in the dry season the soil dries until it cracks. Furthermore, viewed from the aspect of funding, the Government of West Java Province has a limited budget for road management in the southern part of West Java so that the implementation of road construction that is supposed to be changed to the road improvement program will be a periodic road maintenance program [15]. The selection of road construction carried out is adjusted to the existing soil conditions, namely for the surface layer used AC-WC (Asphalt Cement Wearing Course), for the upper foundation layer used CTB (Cement Treated Base), and for the lower foundation layer used Class A aggregate [13], as presented in figure 3 .

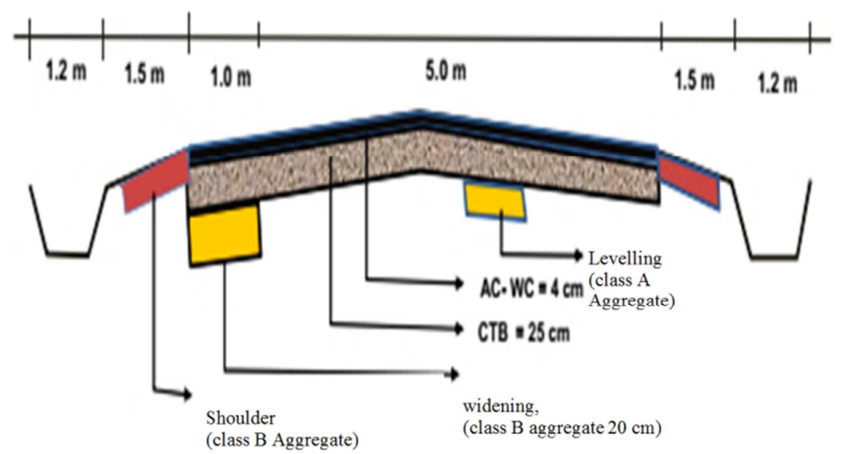

Figure 3. Design of Road Pavement Structure. 
In the implementation of periodic road maintenance work, the quarry for coarse and fine aggregates in the West Java region of southern Java is very limited and at the same time there are many project works that both require aggregate. Therefore a modification of the road pavement structure is needed to save time and implementation costs. One of them is to make CTB aggregate mixture and class A aggregate mixture from the same aggregate fraction, so that one aggregate production from stone crusher produces 2 different mixtures.

\section{Method}

\subsection{Literatur Review}

\subsubsection{Road Periodic Maintenance}

Road implementation is an activity that includes the regulation, guidance, construction and supervision of roads. In road construction, activities are carried out consisting of programming and budgeting, technical planning, construction implementation, and operation and maintenance. While maintenance includes routine maintenance, periodic maintenance and rehabilitation [4]. Road periodic maintenance is an activity to prevent broader road damage and any damage that is taken into account in the design so that the decline in road conditions can be returned to the condition of stability as planned [3].

Periodic maintenance, which covers activities on a section of road at regular and relatively long intervals, aims "to preserve the structural integrity of the road". These operations tend to be large scale, requiring specialized equipment and skilled personnel. They cost more than routine maintenance works and require specific identification and planning for implementation and often even design. Activities can be classified as preventive, resurfacing, overlay, and pavement reconstruction. Resealing and overlay works are generally undertaken in response to measured deterioration in road conditions. For a paved road repaving is needed about every eight years; for a gravel road re-graveling is needed about every three years [2].

Operations that are occasionally required on a section of road after a period of a number of years. They are normally large scale and require specialist equipment and skilled resources. These operations are costly and require specific identification and planning. Periodic maintenance of road also includes certain improvement works such as thin bituminous overlays [7].

\subsubsection{Cement Treated Base}

Chemical changes in soil grains will change the soil structure by forming better aggregate grains. Chemical soil stabilization is a process carried out with additives or additives; the stabilization function is to improve the quality of the subgrade to be able to withstand the load acting on it [11]. Stabilization of soil using lime, coal ash, cement on a deposit, and clay can reduce the soil plasticity index value, liquid limit value, development or significant soil shrinkage [1]. Likewise, CTB is an aggregate mixture with a foundation layer using soil stability material, namely cement. Cement-Treated Base is a base course on flexible pavement and is a development of soil cement foundation. Although the method of making and the end result is concrete, CTB is not a development of rigid pavement. In anticipating road damage due to the growth of heavy vehicle traffic volume in industrial areas, ports, and expansive land, CTB type pavement is an alternative that can be used to replace asphalt-treated base (ATB) as one of the flexible pavement foundations [6].

Cement-treated base consists of a mixture of Portland Cement, fine aggregate, coarse aggregate, and water or with a mixture of other added ingredients that form a solid mass. Cement-treated base is used as a structural material because it has several advantages, including: easy to print, strong against press, and can be cast in place. Besides the advantages, CTB also has weaknesses, namely having an average strength value of $83 \%$ of the compressive strength of the concrete cube with ribs of $15 \mathrm{~cm}$, so that it has a low tensile stress which is not flexible and the volume of concrete is unstable due to shrinkage [11].

The compressive strength of a Cement Treated Base (Base) is the amount of load per unit area, which causes the cylindrical specimen to disintegrate when it is burdened with a certain compressive force, which is produced by a press machine. The modulus of elasticity of CTB has a relationship with other concrete properties, especially the strength itself. This modulus is the stress value divided by the CTB strain under elastic conditions where the stress reaches the maximum compressive strength [5]. The mixing of CTB pavement layers on roads in the southern part of West Java refers to several Reference Standards, as presented in Table 1 [5].

Table 1. Reference Standard of CTB Pavement.

\begin{tabular}{lll}
\hline Num & Standard Code & Descriptions \\
\hline 1 & SII -13-1997 & Portland Cement \\
2 & AASHTO T 26-72 & Quality of Water to be used in Concrete \\
3 & AASHTO T 104 - 77 & Soundness of Aggregate by use or Sodium Sulphate \\
4 & AASHTO T $89-68$ & Determining the Liquid Limit of Soil \\
5 & AASHTO T 90 - 70 & Determining the Plastic Limit and Plasticity Index of Soil \\
6 & AASHTO T 96 - 74 & Resistance of Abrasion of Small Size Coarse Aggregate by use of the Los Angeles Machine \\
7 & AASHTO T 112 - 78 & Clay Lump and Friable Particle in Aggregate \\
8 & AASHTO T 191 - 61 & Density of Soil in Place by Sand Cone \\
9 & AASHTO T 22 - 90 & Compressive Strength of Cylindrical Concrete Specimen \\
10 & AASHTO T 134 - 70 & Moisture - Density Relations of Soil - Cement Mixtures \\
\hline
\end{tabular}




\begin{tabular}{lll}
\hline Num & Standard Code & Descriptions \\
\hline 11 & AASHTO T $144-74$ & Cement Content of Soil Cement Mixtures \\
12 & AASHTO T 205 - 64 & Density of Soil in Place by the Rubber-Balloon Method \\
13 & AASHTO T 224 - 67 & Correction for Coarse Particles in the Soil Compaction Test \\
14 & AASHTO T 27 - 74 & Sieve Analysis of Fine and Course Aggregates \\
15 & AASHTO T $147-65$ & Materials for Aggregate and Soil - Aggregate Subbase, Base and Surface Courses \\
16 & AASHTO M $81-70$ & Cut-back Asphalt (Rapid Curing Type) \\
17 & AASHTO M $82-70$ & Cut-back Asphalt (Medium - Curing Type) \\
18 & AASHTO M $140-70$ & Emulsified Asphalt \\
19 & AASHTO M $141-70$ & Slow-Curing Liquid Asphaltic Road Material \\
20 & AASHTO M 208-72 & Cationic Emulsified Asphalt \\
\hline
\end{tabular}

Source: [15].

CTB pavement is a mixture of cement, water and aggregate. Cement must use Type I Cement and refers to the Indonesian Industry Standard, SII -13-1977. For aggregates, it must refer to aggregate gradations and certain mixed properties. The requirements for aggregate gradations and the characteristics of the CTB mixture are presented in Table 2 and Table 3.

Table 2. Gradations of CTB Aggregate.

\begin{tabular}{lll}
\hline No. & Sieve Sizes $(\mathbf{m m})$ & \% Pass \\
\hline 1 & 50.00 & 100 \\
2 & 37.50 & $95-100$ \\
3 & 19.00 & $45-80$ \\
4 & 4.75 & $25-50$ \\
5 & 2.35 & $8-30$ \\
6 & 1.18 & $0-8$ \\
7 & 0.075 & $0-5$ \\
\hline
\end{tabular}

Table 3. Requirements of Characteristic CTB Mixed.

\begin{tabular}{|c|c|c|c|}
\hline No. & Mixed Characteristic & AASHTO Standard & Requirements \\
\hline 1 & $\begin{array}{l}\text { Abrasion of Coarse } \\
\text { Aggregate }\end{array}$ & T96 - 74 & $\operatorname{Max} 35 \%$ \\
\hline 2 & Liquid Limit & T89 - 68 & $\operatorname{Max} 35 \%$ \\
\hline 3 & Clay Lump and Friable & T112- 78 & $\operatorname{Max} 1 \%$ \\
\hline
\end{tabular}

\begin{tabular}{|c|c|c|c|}
\hline No. & Mixed Characteristic & AASHTO Standard & Requirements \\
\hline 4 & $\begin{array}{l}\text { Particles in Aggregate } \\
\text { Plasticity Index }\end{array}$ & T90 - 70 & Max 6\% \\
\hline
\end{tabular}

Before the periodic maintenance of the road with CTB pavement, the mixture design was first made to determine the compressive strength of the CTB pavement, the required cement content, optimum water content, and the dry weight of the mixture at optimum water content. Unconfined compressive strength from the CTB pavement $\left(\mathrm{kg} / \mathrm{cm}^{2}\right)$ is equivalent to concrete with a compressive strength of $70 \mathrm{~kg} / \mathrm{cm}^{2}$ at a 7 -day bath for the test cylinder $(150 \mathrm{~mm} \times$ $150 \mathrm{~mm}$ ) or compressive strength of $120 \mathrm{~kg} / \mathrm{cm}^{2}$ at 28 days immersion.

\subsubsection{Agregate Class $A$}

Besides using CTB pavement, in implementation of Road Periodic Maintenance on Sindangbarang - Agrabinta Section it also uses a subbase with class A aggregates, for the subbase layer using class A aggregate with a thickness of $20 \mathrm{~cm}$. Like $\mathrm{CTB}$, the class A aggregate refers to the reference, as in Table $4[5]$.

Table 4. Reference Standards of Class A Aggregate.

\begin{tabular}{lll}
\hline Num & Standard Code & Descriptions \\
\hline 1 & SNI 03-1967-1990 (AASHTO T 89 - 90) & Liquid Boundary Testing Method with Cassagrande Tool \\
2 & SNI 03-1966-1990 (AASHTO T 90 - 87) & Plastic Limit Testing Method \\
3 & SNI 03-2417-1991 (AASHTO T 96 - 87) & Aggregate Wear Testing Method with a Los Angeles Machine \\
4 & SK SNI M-01-1994-03 (AASHTO T112-87) & Methods for Testing Clumps of Clusters and Easy Items to Break in the Aggregate \\
5 & SNI 03-1743-1989 (AASHTO T180 - 90) & Method of Testing Heavy Density for Soil \\
6 & SNI 03-2827-1992 (AASHTO T191 - 86) & Field Density Testing Method with Sand Conus \\
7 & SNI 03-1744-1989 (AASHTO T193 - 81) & Laboratory CBR Testing Method \\
\hline
\end{tabular}

Source: [15].

The class A aggregate is a mixture of coarse aggregate and fine aggregate. Coarse aggregate is the size of the aggregate held in a $4.75 \mathrm{~mm}$ filter, which consists of particles or hard and durable rock or gravel, while the fine aggregate is the size of the aggregate that passes the $4.75 \mathrm{~mm}$ filter, which consists of natural sand particles or fine broken rocks and other fine particles. Aggregate requirements refer to the gradations and characteristics of the mixture, as presented in Table 5 and Table 6.

Table 5. Gradations of Class A Aggregate.

\begin{tabular}{llll}
\hline \multirow{2}{*}{ No. } & Sieve Sizes $(\mathbf{m m})$ & & \multirow{2}{*}{ Pass } \\
\cline { 2 - 4 } & ASTM & $\mathbf{( m m})$ & - \\
& $2 ”$ & 50 & 100 \\
2 & $11 / 2 ”$ & 37.5 & $79-85$ \\
3 & $1 ”$ & 25.0 & $44-58$ \\
4 & $3 / 8 ”$ & 9.50 & \\
\hline
\end{tabular}




\begin{tabular}{llll}
\hline \multirow{2}{*}{ No. } & Sieve Sizes $(\mathbf{m m})$ & \% Pass \\
\cline { 2 - 4 } & ASTM & $\mathbf{( m m})$ & $29-44$ \\
5 & No. 4 & 4.75 & $17-30$ \\
6 & No. 10 & 2.0 & $7-17$ \\
7 & No. 40 & 0.425 & $2-8$ \\
\hline
\end{tabular}

Source: [15].

Table 6. Characteristic of Class A Aggregate Mix.

\begin{tabular}{llll}
\hline No. & Mixed Characteristic & AASHTO Standard & Requirements \\
\hline 1 & Abrasion from Coarse Aggregates & SNI 03-2417-1990 & $0-40 \%$ \\
2 & Plasticity Index & SNI-03-1966-1990 & $0-6$ \\
3 & Results times the Index of Plasticity with \% Pass the Sieves No. 200 & - & max. 25\% \\
4 & Liquid Limit & SNI 03-1967-1990 & $0-25 \%$ \\
5 & The Part of soft & SK SNI M-01-1994-03 & $0-5 \%$ \\
6 & CBR & SNI 03-1744-1989 & min. 90\% \\
\hline
\end{tabular}

Source: [15].

\subsection{Pavement Structure and Research Location}

The study was conducted on the Sindangbarang Agrabinta road section between km. bdg. $174+208$ to $\mathrm{km}$. bdg. $185+513$. The location is in Cianjur Regency, West Java Province, Indonesia. The status of the road is a provincial strategic road which functions as a primary collector road. The handling of the road alignment is funded by the Regional Government of West Java Province through Road and Bridge Periodic Maintenance activities. The pavement structure on the maintenance of this road is presented in Figure 4.

\begin{tabular}{|c|c|}
\hline Surface: AC-WC, Thickness $=4 \mathrm{~cm}$ & Surface: AC-WC, Thickness $=4 \mathrm{~cm}$ \\
\hline Base Course: $\mathbf{C T B}$, Thickness $=\mathbf{2 5 \mathrm { cm }}$ & Base Couse: CTB, Thickness $=\mathbf{2 5} \mathrm{cm}$ \\
\hline $\begin{array}{c}\text { Subbase: } \text { Class A Aggregate Levelling } \\
\text { Thickness }=\mathbf{2 0 \mathrm { cm }}\end{array}$ & $\begin{array}{l}\text { Subbase: } \text { Class A Aggregate } \\
\text { Thickness }=\mathbf{2 0 \mathrm { cm }}\end{array}$ \\
\hline Original Soil & Original Soil \\
\hline Overlay & Widening \\
\hline
\end{tabular}

Figure 4. Road Pavement Structure Existing and Widening.

Based on the calculation of the volume of work, an aggregate is needed for CTB pavement and class A aggregate base layer. The aggregate consists of: $2-3 \mathrm{~cm}$ broken stone, broken stone, $1-2 \mathrm{~cm}$, broken stone $0.5-1 \mathrm{~cm}$, and sand. The size and type of aggregate for CTB and class A are the same, which differs only in proportion to each aggregate size. The aggregate mining location has only one quarry location which is in Cidaun sub-district. The location of the quarry research and retrieval are presented in Figure 5.

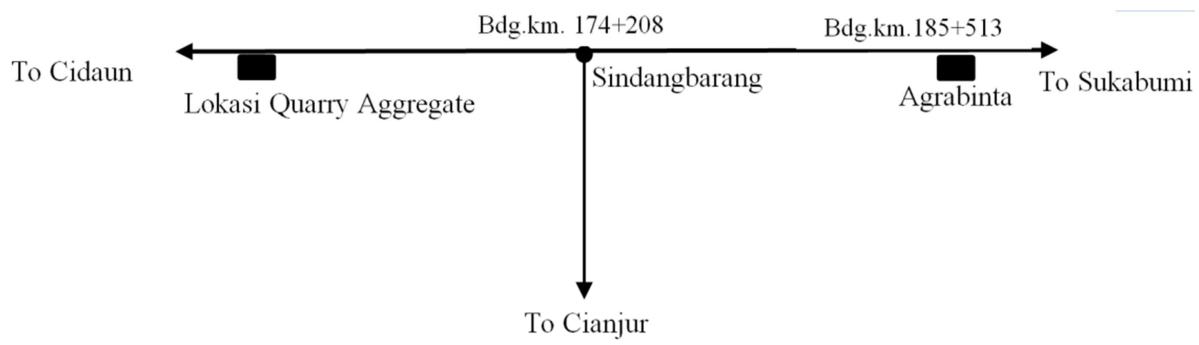

Figure 5. Location Study and Quarry of CTB and Class A Aggregate.

\subsection{Testing of Aggregate}

To find out the nature or characteristics of the road material and the amount of mixed fraction to be used, laboratory testing and mixed planning must be carried out. In this study, road material testing was carried out on materials for a mixture of CTB, a mixture of LPA and CTB using class aggregates. Material testing was carried out at the Land and Road Testing Laboratory of the Public Works and Spatial Planning Office of Cianjur Regenc West Java. The type of testing is presented in Table 7. 
Table 7. Types of Material Testing.

\begin{tabular}{lll}
\hline No. & Jenis Pengujian Type of Testing & Description \\
\hline 1 & CTB Aggregate and Mixture & Aggregate testing and CTB Pavement mix design \\
2. & LPA Aggregates and Mixtures & Aggregate testing and percentage of aggregate fractions of Class A foundations \\
3. & Class A Aggregates for CTB Mixtures & Aggregate testing and mix design of CTB Pavement with class A aggregate \\
\hline
\end{tabular}

Source: Spec.

Mixed design cement-treated base with compressive strength $\mathrm{K}-125 \mathrm{~kg} / \mathrm{cm}^{2}$ was carried out using the mix design trial method [10]. The design of CTB pavement mixture with class A aggregate using the DOE (Department of the Environment) method was revised in 1988 [9]. It was also done making cubes with a size of $15 \mathrm{~cm} \times 15 \mathrm{~cm} \times 15 \mathrm{~cm}$, testing cement-treated base aged 28 days, as well as testing the compressive strength of test specimens.

\section{Result}

\subsection{Research Data}

Research data in the form of a mixture of aggregate for class A and CTB, which consists of coarse aggregate, fine aggregate, cement, and water. Class A aggregate consists of coarse aggregate and is a type of broken stone with a maximum nominal of $20 \mathrm{~mm}$, content weight of $1.41 \mathrm{~kg} /$ liter, aggregate absorption of $0.83 \%$, and percentage of aggregate gradation combined $55 \%$. For fine aggregate is a type of natural sand with a maximum nominal b20mm, weight of $1.34 \mathrm{~kg} /$ liter, aggregate absorption of $17.98 \%$, and percentage of aggregate gradation combined $45 \%$. Portland cement is type I cement, the brand of Tiga Roda, 2.15 specific gravity, and other properties meet ASTM C 150-1996 standards.

CTB hardening consists of coarse aggregate and is a type of broken stone, the maximum nominal grain is $20 \mathrm{~mm}$, content weight is $1.4 \mathrm{~kg} /$ liter, aggregate absorption is $0.83 \%$, percentage aggregate gradation is $70 \%$ combined, fine aggregate is a type of sand, maximum nominal $20 \mathrm{~mm}$, weight of $1.34 \mathrm{~kg} /$ liter, aggregate absorption (absorbtion) $17.98 \%$, and the percentage of aggregate gradation combined $30 \%$. Portland Type I cement, Tiga Roda brand, 2.15 specific gravity, minimum cement content of $250\left(\mathrm{~kg} / \mathrm{m}^{3}\right.$ of mixture), and other properties meet ASTM C 150-1996 standards.

\subsection{Laboratory Test Results}

The testing of aggregate characteristics and characteristics for CTB and class A aggregates consists of sieve analysis, abrasion of aggregate aggregates, plasticity index, liquid limit and clay lamp and friable practice in aggregate. The results of the aggregate filter analysis for CTB and the aggregate for Class $\mathrm{A}$ are still between the minimum and maximum limits, as presented in Figure 6 and Figure 7. While the Aggregate characteristics and aggregate are based on the testing of aggregate abrasion of coarse, plasticity index, liquid limit and clay lamp and friable practicle in aggregate, generally meet the requirements.

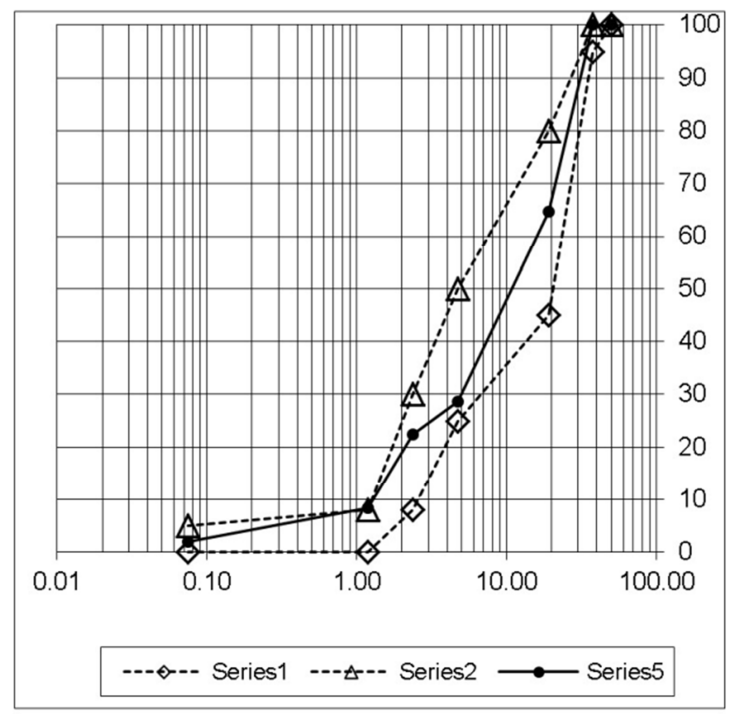

Figure 6. Sieve Analysis of CTB.

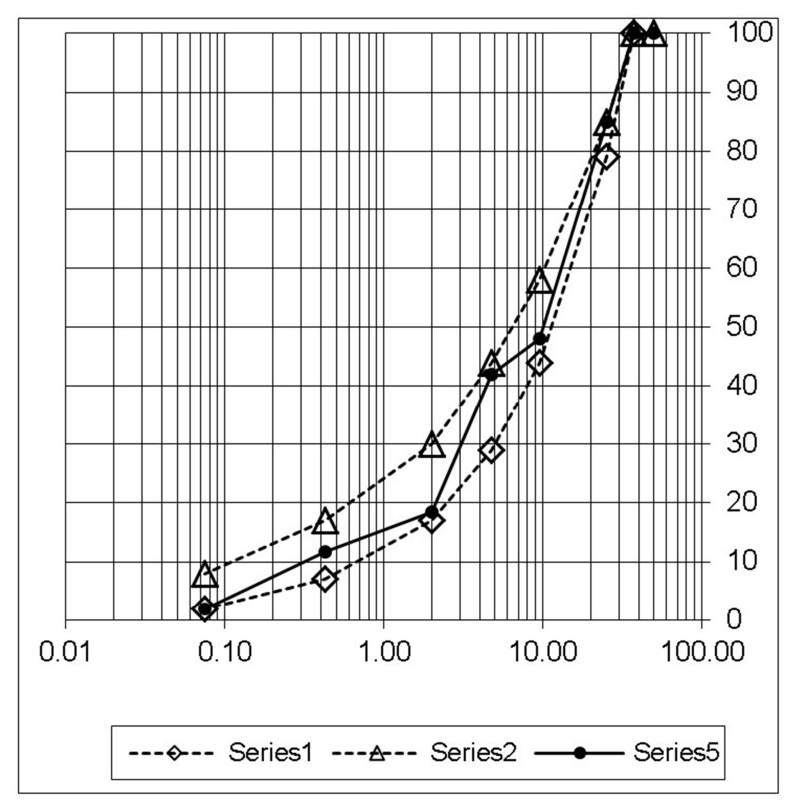

Figure 7. Sieve Analysis of Class A Aggregate.

\subsection{Mix Design}

Mix design of CTB is done by two methods. Mix design of CTB using LPA aggregates and cement in which it is planned that the $125 \mathrm{~kg} / \mathrm{cm}^{3}$ compressive strength is carried out using the DOE (Department Of Environment) method. Mix design of CTB using aggregates CTB is planned with $125 \mathrm{~kg} / \mathrm{cm} 125$ compressive strength carried out by the trial mix method. The 
results of the mix design of CTB with LPA and cement are presented in Table 8, mix design of CTB mixtures with CTB

aggregates in Table 9.

Table 8. Proportion of Weight and Volume CTB with Class A Aggregates, Compressive Strength $125 \mathrm{~kg} / \mathrm{cm}$.

\begin{tabular}{|c|c|c|c|c|c|}
\hline \multirow{2}{*}{\multicolumn{2}{|c|}{ Type of Mixed Material }} & \multirow{2}{*}{$\begin{array}{l}\text { Composition } 1 \mathrm{M}^{3} \text { Concrete of } \\
\text { Aggregate SSD }\end{array}$} & \multirow{2}{*}{$\begin{array}{l}\text { Composition } 1 \mathrm{M}^{3} \text { Concrete of Water } \\
\text { Content Corrected Aggregate }\end{array}$} & \multicolumn{2}{|c|}{ Comparison } \\
\hline & & & & Weight & Volume \\
\hline 1 & Portland Cement & 341.67 & 341.67 & 1.00 & 1.00 \\
\hline 2 & Water, liter & 205.00 & 352.42 & 1.03 & 2.08 \\
\hline 3 & Fine Aggregate, kg & 878.00 & 791.27 & 2.31 & 3.41 \\
\hline 4 & Course Aggregate, $\mathrm{kg}$ & 1075.00 & 1076.8 & 3.15 & 4.74 \\
\hline
\end{tabular}

Table 9. Proportion of Weight and Volume CTB with CTB Aggregates, Compressive Strength $125 \mathrm{~kg} / \mathrm{cm}$.

\begin{tabular}{|c|c|c|c|c|c|}
\hline \multirow{2}{*}{\multicolumn{2}{|c|}{ Type of Mixed Material }} & \multirow{2}{*}{$\begin{array}{l}\text { Composition } 1 \mathrm{~m}^{3} \text { Concrete of } \\
\text { Aggregate SSD }\end{array}$} & \multirow{2}{*}{$\begin{array}{l}\text { Composition } 1 \mathrm{~m}^{3} \text { Concrete of Water } \\
\text { Content Corrected Aggregate }\end{array}$} & \multicolumn{2}{|c|}{ Comparison } \\
\hline & & & & Weight & Volume \\
\hline 1 & Portland Cement, & 250.00 & 250.00 & 1.00 & 1.00 \\
\hline 2 & Water, liter & 17.75 & 124.02 & 0.50 & 1.00 \\
\hline 3 & Fine Aggregate, kg & 750.00 & 690.00 & 2.76 & 2.70 \\
\hline 4 & Coarse Aggregate, $\mathrm{kg}$ & 1750 & 647.50 & 2.59 & 3.20 \\
\hline
\end{tabular}

\subsection{Testing of Concrete Press Strength}

Concrete strength test results must be evaluated by multiplying the correction factor for the number of test objects to get the value of the compressive strength that it represents. Evaluation of calculation of compressive strength is presented in Table 10 for CTB with class A aggregate and Table 11 for CTB with aggregate CTB.

Table 10. Strength Press Concrete from CTB with Class A Aggregate.

\begin{tabular}{lllll}
\hline No Object Test & Testing Age & $\boldsymbol{\sigma i}$ at $\mathbf{2 8}$ days old & $\boldsymbol{\sigma i}-\boldsymbol{\sigma b m}$ & $(\boldsymbol{\sigma i}-\boldsymbol{\sigma b m})^{\mathbf{2}}$ \\
\hline 1 & 28 & 120.50 & -28.96 & 838.6816 \\
2 & 28 & 122.55 & -26.91 & 724.1481 \\
3 & 28 & 125.55 & -23.91 & 571.6881 \\
4 & 28 & 135.55 & -13.91 & 518.0176 \\
5 & 28 & 172.22 & 22.76 & 444.7881 \\
6 & 28 & 170.55 & 21.09 & 681.2100 \\
7 & 28 & 175.56 & 26.10 & 563.5876 \\
8 & 28 & 173.20 & 23.74 & \\
$\Sigma$ & & 1195.68 & & 4535.6092 \\
\hline bm (average) & & 149.46 & & \\
\hline
\end{tabular}

$\sigma \mathrm{bk}=\sigma \mathrm{bm}-(1.645 \times \mathrm{s}) \times \mathrm{k}$.

$\sigma \mathrm{bk}=127.7 \mathrm{Kg} / \mathrm{cm}^{2}>125 \mathrm{~kg} / \mathrm{cm}^{2}$ (minimum required)... OK.

Table 11. Strength Press Concrete from CTB with CTB Aggregate.

\begin{tabular}{lllll}
\hline No Object Test & Testing Age & $\boldsymbol{\sigma i}$ at $\mathbf{2 8}$ days old & $\boldsymbol{\sigma i}-\boldsymbol{\sigma b m}$ & $(\boldsymbol{\sigma} \mathbf{i}-\boldsymbol{\sigma b m})^{\mathbf{2}}$ \\
\hline 1 & 28 & 120.50 & -28.375 \\
2 & 28 & 120.55 & -28.325 \\
3 & 28 & 125.25 & -23.625 & 805.1406 \\
4 & 28 & 133.55 & -15.325 & 502.3056 \\
5 & 28 & 172.55 & 23.675 & 234.8556 \\
6 & 28 & 172.55 & 23.675 & 560.5056 \\
7 & 28 & 174.55 & 25.675 & 560.5056 \\
8 & 28 & 171.50 & 22.625 & 659.2056 \\
$\Sigma$ & & 1191.00 & & 511.8906 \\
$\Sigma$ bm (average) & & 148.88 & & 4692.5500 \\
\hline
\end{tabular}

$\sigma \mathrm{bk}=\sigma \mathrm{bm}-(1.645 \times \mathrm{s}) \times \mathrm{k}$.

$\sigma \mathrm{bk}=126.80 \mathrm{Kg} / \mathrm{cm}^{2}>125 \mathrm{~kg} / \mathrm{cm}^{2}$ (minimum required)... OK.

\section{Discussion}

Periodic maintenance of roads in the southern part of West Java Province, in accordance with the planning documents of the Government of West Java Province, is carried out with AC-WC pavement construction for surface layers, CTB for upper foundation layers, and class A aggregates for lower foundation layers. CTB mixture, and class A aggregate foundation layers have different aggregate fraction compositions. so the stone crusher takes twice to make a CTB aggregate mixture and class A aggregate. To reduce the aggregate mixing time by the stone crusher, a one time mixing is made to produce two types of pavement, CTB and 
class A aggregate foundation layer.

The results of the analysis of the aggregate and mix design using the trial mix method, produced a class A aggregate mixture for the bottom foundation layer and a class A aggregate mixture plus cement for CTB. This method can save stone crusher time in making aggregate fractions for class A and CTB aggregate mixtures. Concrete compressive strength test results, a mixture of CTB with CTB aggregates produces concrete compressive strength of $126.80 \mathrm{~kg} / \mathrm{cm}^{2}>$ $125 \mathrm{~kg} / \mathrm{cm}^{2}$ (greater than the minimum compressive strength required) and concrete compressive strength test results, CTB mixture made from aggregate class $B$ added with cement produces concrete compressive strength of $127.7 \mathrm{~kg} / \mathrm{cm}^{2}>$ $125 \mathrm{~kg} / \mathrm{cm}^{2}$ (greater than the minimum compressive strength required).

\section{Conclusion}

Cement Treated Base (CTB) is used as a top foundation layer for subgrade that has poor carrying capacity. CTB material is a mixture of coarse aggregate and fine aggregate plus cement to achieve unconfine compressive strength which is equivalent to concrete with compressive strength of $125 \mathrm{~kg} / \mathrm{cm}^{2}$. The pavement structure planning in the road improvement project in the South West Java Region consists of AC-WC (as surface layer), CTB (as upper foundation layer) and Class A aggregate (as lower foundation layer), so that the aggregate needed is not only aggregate for CTB but also the aggregate for class A aggregate foundation layers. Making the aggregate by stone crusher requires twice the making and mixing of aggregates, i.e. aggregates for CTB and aggregates for class A foundation layers. To achieve time savings in implementation, the CTB mixing is modified. using aggregate from class A aggregate job mix, only added with cement, so that once a stone crusher is mixed just enough for the CTB mixture and class A aggregate foundation layer Profortion of CTB mixture volume using class A aggregates being: portland cement $(1 \%)$, water $(2,08 \%)$, fine aggregate $(3.41 \%)$, and coarse aggregate (4,74\%). While the results of the concrete compressive strength test on the mixture of Cement Treated Base (CTB) with CTB aggregate obtained an average compressive strength value of $126,80 \mathrm{~kg} / \mathrm{cm}^{2}$ greater than the planned compressive strength of $125 \mathrm{~kg} / \mathrm{cm}^{2}$. For CTB mixture using aggregate class $\mathrm{A}$, the average compressive strength value of $127.70 \mathrm{~kg} / \mathrm{cm}^{2}$ is greater than the planned compressive strength of $125 \mathrm{~kg} / \mathrm{cm}^{2}$. After modification of the pavement type, the road pavement structure becomes a surface layer with asphalt concrete (AC-WC) $4 \mathrm{~cm}$ thick, the upper foundation layer uses Cement Treated Base (CTB) with a class A aggregate $20 \mathrm{~cm}$ thick, the bottom layer of the base layer aggregate foundation class A $20 \mathrm{~cm}$ thick, and native soil as a subgrade.

\section{References}

[1] Bowles, J, E., Analysis and design of foundation volume 1, Erlangga; Jakarta, 1997.

[2] Burningham S, and Natalya Stankevich N, 2005, why road maintenance is important and how to get it done, The World Bank, Washington, Dc Transport Note No. Trn-4 June 2005.

[3] Government of the Republic of Indonesia, Minister of Public Works Regulation No. 13 of 2012 Concerning Road Maintenance and Ownership Procedures, Jakarta, 2012.

[4] Government of the Republic of Indonesia, Government Regulation Number 34 of 2006 concerning Roads, Jakarta, 2006.

[5] Government of the Republic of Indonesia, Ministry of Public Works, Directorate General of Highways, General Specifications of Roads and Bridges, 2010.

[6] Herman and Edwar J, The Effect of Cement Variation on the Flexural Type CBR Base Cement Treated Base (CTB) Value, Journal of Civil Engineering Foundation, Volume 10 No. 2, October, 2014.

[7] International Road Maintenance Handbook, Practical Guidelines For Rural Road Maintenance, Transport Research Laboratory, United Kingdom, 2005.

[8] Kezdi, A., Stabilized Earth Road, Elsvier Scientific Publishing Company, New York, 1979.

[9] Mulyono, T, Concrete Technology, Yogyakarta, 2005.

[10] National Standardization Body, Procedure for making normal concrete mix plans, SNI 03-2834-2000, Jakarta, 2000.

[11] Nusantoro, A, Alami N, and Nurkholis, Strength Analysis of Cement Treated Base (CTB) with Additive Substances Addition Using Soil Content Variations, The 7th University Research Colloqium, Muhammadiyah University, 2018.

[12] West Java Provincial Government, West Java Provincial Medium-Term Development Plan (2018-2023), Bandung, 2018.

[13] West Java Provincial Government, Road and Bridge Design Documents on Sindangbarang - Agrabinta Roads, Bandung, 2015.

[14] West Java Chamber of Commerce and Industry (KADIN), Spur Economic Competitiveness in South West Java, 2012.

[15] West Java Provincial Government, Strategic Plan of the Highways Office of West Java Province 2013-2018, Bandung, 2017.

[16] West Java Provincial Government, Report on the Results of the Soil Investigation Survey on SindangbarangAgrabinta-Tegalbuleud Roads, Bandung, 2013. 